\title{
A Boophilus microplus vitellin-degrading cysteine endopeptidase
}

\author{
A. SEIXAS ${ }^{1,2}$, P. C. DOS SANTOS ${ }^{1,2} \dagger$, F. F. VELLOSO ${ }^{1}$, I. DA SILVA VAZ JR ${ }^{1,3}$, \\ A. MASUDA ${ }^{1,4}$, F. HORN ${ }^{1,5}$ and C. TERMIGNONI ${ }^{1,2 *}$ \\ ${ }^{1}$ Centro de Biotecnologia, ${ }^{2}$ Departamento de Bioquímica, ${ }^{3}$ Departamento de Patologia Clínica Veterinária, \\ ${ }^{4}$ Departamento de Biologia Molecular e Biotecnologia, ${ }^{5}$ Departamento de Biofísica, Universidade Federal do Rio Grande do Sul, \\ P.O. Box 15005, 91501-970, Porto Alegre, RS, Brasil
}

(Received 16 Fuly 2002; revised 8 October 2002; accepted 8 October 2002)

\section{S U M M A R Y}

Here we describe the purification and characterization of a vitellin (VT) degrading cysteine endopeptidase (VTDCE) from eggs of the hard tick Boophilus microplus. A homogeneous enzyme preparation was obtained by chromatographic fractionation on ion-exchange and gel filtration columns and an autolysis step. This step consisted of incubation of a semipurified enzyme (after the first ion-exchange chromatography) at $\mathrm{pH} 4 \cdot 0$ that dissociated the enzyme from VT, to which VTDCE is naturally tightly associated. The enzyme purity was confirmed by capillary and native gel electrophoresis, and SDS-PAGE suggested the enzyme is a dimer of 17 and $22 \mathrm{kDa}$. VTDCE was active upon several synthetic substrates, with a preference for a hydrophobic or a basic residue in $\mathrm{P}_{1}$, and a hydrophobic residue in $\mathrm{P}_{2}$. VTDCE also hydrolysed haemoglobin, albumin, gelatin and vitellin. VTDCE is inactive in the absence of DTT and was totally inhibited by E-64, indicating it is a cysteine endopeptidase. Our results suggest that VTDCE is a major enzyme involved in yolk processing during B. microplus embryogenesis.

Key words: tick, Boophilus microplus, cysteine endopeptidase, vitellin, embryogenesis.

\section{INTRODUCTION}

The embryo development of an arthropod requires that the proper nutrients be available at the right time. The bulk volume of the arthropod eggs are comprised of yolk granules or spheres, specialized organelles that contain reserve material and the enzymatic machinery necessary to make these reserves available. Yolk granules thus provide aminoacids, carbohydrates and lipids for the embryonic process.

The major protein contained within yolk granules is vitellin (VT), a heme-containing phosphoglycolipoprotein derived from a maternal serum protein precursor, vitellogenin (Canal et al. 1995). In many species, such as the tick Ornithodoros moubata (Fagotto, 1991), the cockroach Blatella germanica (Liu, McCarron \& Nordin, 1996), the sea urchins Strongilocentrotus purpuratus and Lytechinus pictus (Mallya et al. 1992), the frog Xenopus laevis (Fagotto \& Maxfield, 1994) and the mosquito Aedes aegypti (Cho et al. 1999), VT degradation is triggered by a developmentally regulated acidification of the yolk granules. This acidification, in turn, activates different

* Corresponding author: Centro de Biotecnologia, Universidade Federal do Rio Grande do Sul, P.O. Box 15005, 91501-970, Porto Alegre, RS, Brasil. Tel: +555133166092. Fax: +555133167309. E-mail: trmgn@dna.cbiot.ufrgs.br

$\dagger$ Present address: Department of Biochemistry, Virginia Tech, Blacksburg, VA, USA 24061. proteinases involved in arthropod yolk digestion, among them acid cysteine proteinases from the cathepsin-like group, mainly cathepsin L-like (Fagotto, 1990) and cathepsin B-like (Medina, Leon \& Vallejo, 1988).

A previous report has shown that acidification, and the consequent activation of an acid aspartic proteinase, is required for yolk degradation in the cattle tick Boophilus microplus (Logullo et al. 1998). In this work we report the presence of a (cathepsin L-like) cysteine endopeptidase, which is associated with vitellin, in eggs of B. microplus and that probably has a role in the VT degradation during $B$. microplus embryogenesis.

MATERIALS AND METHODS

\section{Materials}

All the 7-amido-4-methylcoumarin (MCA) fluorogenic substrates were purchased from Sigma Chemical Co. (St Louis, USA). The internal quenched fluorescence substrate, MCA-Gln-Ser-Ser-Arg-HisArg-Arg-Ala-Leu-Gln-EDDnp (ethylenedinitrophenyl-N-[2.4-dinitrophenyl]-ethylenediamine) was synthesized and kindly supplied by Dr Luiz Juliano (Escola Paulista de Medicina, Universidade Federal de São Paulo, Brazil). Centricon-10 and Microcon10 were from Amicon Inc. (Beverly, USA), the other filters were from Millipore Ind. Com. Ltda (Bedford, USA). B. microplus vitellin was prepared 
according to the method described by Da Silva Vaz Jr, Osaki \& Masuda (1994).

\section{Ticks and eggs}

Ticks from the Porto Alegre strain were reared on bovines, which were brought from a tick-free area and maintained in insulated individual boxes protected from contact with other ticks and insects. Bovines were infested with 15-day-old (from hatching) B. microplus larvae. After 22 days, engorged adult female ticks that had spontaneously detached from the host were collected and incubated at $28{ }^{\circ} \mathrm{C}$ and $85 \%$ relative humidity. Eggs from the 1 st to the 12 th day after oviposition were collected and stored at $-70{ }^{\circ} \mathrm{C}$ until used.

\section{Protease activity assays}

Zymograms. The zymogram is a simple and sensitive technique used to detect proteolytic activity. It is particularly useful when the sample may contain more than 1 proteolytic activity. In this work zymograms were used to search for proteases in 3 different tick crude extracts and to evaluate the enzyme capacity to hydrolyse different proteins. Assays were done according to the method of Heussen \& Dowdle (1980). Briefly, polyacrylamide gels $(7 \cdot 5 \%)$ copolymerized with $0 \cdot 1 \%$ gelatin, $0 \cdot 1 \%$ haemoglobin, $0 \cdot 1 \%$ vitellin, $0 \cdot 1 \%$ albumin or $0 \cdot 1 \%$ ovalbumin were run under non-denaturing conditions (without sodium dodecyl sulfate (SDS)) in $50 \mathrm{~mm}$ Tris-glycine buffer, $\mathrm{pH} 8 \cdot 3$. After the electrophoretic separation, gels were washed and incubated overnight in $0.1 \mathrm{M}$ sodium acetate buffer, $\mathrm{pH} 3 \cdot 5$, containing $5 \mathrm{~mm}$ dithiothreitol (DTT), at $37^{\circ} \mathrm{C}$. At the end of the incubation period, gels were washed with water and stained with Coomassie Brilliant Blue R-250.

Activity with fluorogenic substrates. Column fractions (10 $\mu \mathrm{l}$ aliquots) or other samples to be tested were incubated with $50 \mathrm{~mm}$ sodium citrate/sodium phosphate buffer, pH $3 \cdot 5$, and $10 \mathrm{~mm}$ DTT at $37^{\circ} \mathrm{C}$. After $10 \mathrm{~min}$, the fluorogenic substrate $N$-Cbz-PheArg-MCA (Cbz, carboxibenzoyl) was added to a final concentration of $1 \cdot 4 \mu \mathrm{M}$ in a total volume $100 \mu \mathrm{l}$. Hydrolysis was monitored at $11 \mathrm{sec}$ intervals by fluorimetry in a fmax Microplate Reader (Molecular Devices Corporation, California, USA). The wavelength pair for excitation and emission was $370 \mathrm{~nm} /$ $460 \mathrm{~nm}$ (Oliveira et al. 1992). MCA concentrations were calculated using standard curves.

The enzyme activity was also tested with MCAGln-Ser-Ser-Arg-His-Arg-Arg-Ala-Leu-Gln-EDD$\mathrm{np}(3 \cdot 6 \mu \mathrm{M}$ final concentration). This substrate, when hydrolysed in any one of its peptide bonds, emits fluorescence of the MCA group, otherwise quenched by the EDDnp group when the substrate is intact. This substrate was efficiently hydrolysed by the cysteine endopeptidase and was therefore used to determine the enzyme's optimum $\mathrm{pH}$ and optimum temperature. The optimum $\mathrm{pH}$ was determined in $50 \mathrm{~mm}$ sodium citrate/sodium phosphate buffer, $10 \mathrm{~mm}$ DTT at several pHs. Optimum temperature was determined in $50 \mathrm{~mm}$ sodium citrate/sodium phosphate buffer, pH 3.5, $10 \mathrm{~mm}$ DTT by incubating the enzyme for $30 \mathrm{~min}$ at different temperatures. Hydrolysis of the substrate was measured by reading the increase in fluorescence at $320 / 430 \mathrm{~nm}$ after the incubation.

\section{Enzyme purification}

Eggs from the 1 st to the 12 th day after oviposition were homogenized in a Potter-Elvehjem tissue grinder with $10 \mathrm{~mm}$ phosphate buffer, pH 7·2 $(0 \cdot 1 \mathrm{~g}$ of eggs/ $\mathrm{ml})$. The homogenate was centrifuged $(16000 \mathrm{~g}$ for $5 \mathrm{~min}$ ) to remove the insoluble material and the supernatant fraction was filtered through a sequence of filters (AP glass fibre filter, $0 \cdot 45 \mu \mathrm{m}$ and $0 \cdot 22 \mu \mathrm{m}$ ). The sample $(7 \mathrm{ml})$ was then applied onto a $0.5 \mathrm{~cm}$ $\times 5.0 \mathrm{~cm}$ Mono Q HR 5/5 (Pharmacia, Uppsala, Sweden) column previously equilibrated with $10 \mathrm{~mm}$ sodium phosphate buffer, $\mathrm{pH} 7 \cdot 2$, and eluted with a $0-0.8 \mathrm{M} \mathrm{NaCl}$ gradient in the same buffer system at room temperature with a flow rate of $0.5 \mathrm{ml} / \mathrm{min}$. Fractions of $1.0 \mathrm{ml}$ were collected. Fractions containing activity $(6-7 \mathrm{ml})$ were pooled and submitted to autolysis. In this step, the pooled fractions were acidified to $\mathrm{pH} 3.5$ with $1.0 \mathrm{M}$ citric acid and incubated at $37^{\circ} \mathrm{C}$ for approximately $3 \mathrm{~h}$, after which the sample was centrifuged at $3000 \boldsymbol{g}$ for $15 \mathrm{~min}$.

After centrifugation, the supernatant fraction was concentrated in a Centricon-10 and applied onto a $1 \cdot 0 \mathrm{~cm} \times 30 \mathrm{~cm}$ Superdex 75 HR (Pharmacia, Uppsala, Sweden) column equilibrated with $10 \mathrm{~mm}$ acetate buffer, pH $4 \cdot 0$, using a Fast-Purification-Liquid Chromatography system (FPLC) at room temperature with a flow rate of $0.3 \mathrm{ml} / \mathrm{min}$. The pool of active fractions was then applied onto a second Mono $\mathrm{Q}$ HR $5 / 5$ column $(0.5 \mathrm{~cm} \times 5.0 \mathrm{~cm})$, previously equilibrated with acetate buffer $10 \mathrm{~mm}, \mathrm{pH} 4 \cdot 0$. The enzyme was eluted with a $0-0 \cdot 8 \mathrm{M} \mathrm{NaCl}$ gradient in the same buffer. Enzyme activity in the fractions was monitored with $\mathrm{N}$-Cbz-Phe-Arg-MCA as substrate.

\section{Protein determination}

Protein concentration was estimated by reading the absorbance at 280 and $260 \mathrm{~nm}$ (Warburg $\&$ Christian, 1941) in a quartz microplate using a SpectraMax microplate reader (Molecular Devices Corporation, California, USA) or in a $1.0 \mathrm{~cm}$ quartz cuvette using a spectrophotometer (Pharmacia, Uppsala, Sweden). Protein concentration of column eluates was monitored by absorbance at $280 \mathrm{~nm}$. 


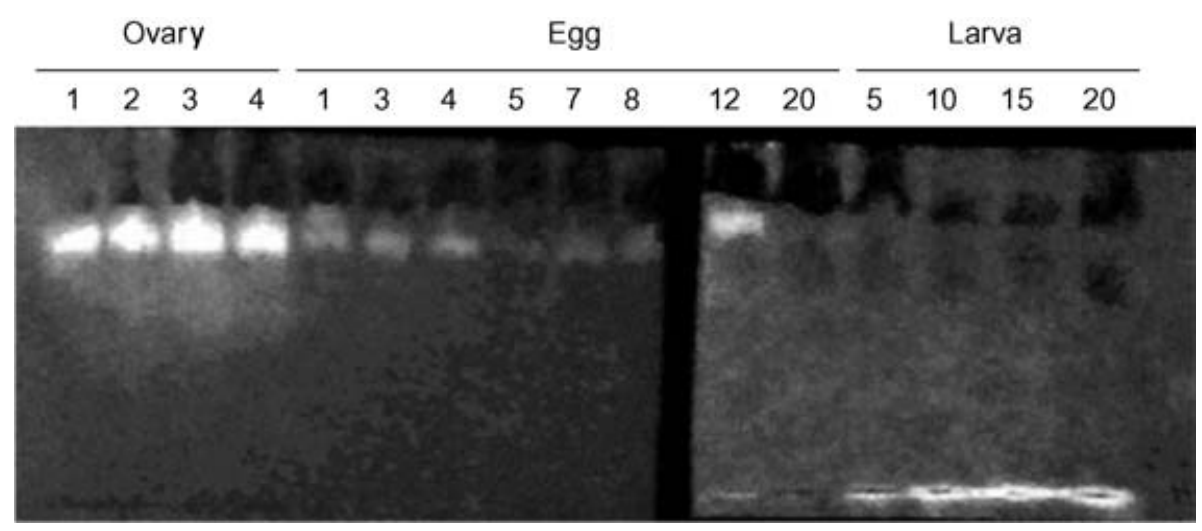

Fig. 1. Analysis by zymogram of the proteolytic activity present in the extracts of Boophilus microplus ovaries, eggs and larvae. The experiment was done using polyacrylamide (6\%) gel electrophoresis containing co-polymerized gelatin $(0 \cdot 1 \%)$, stained with Coomassie R-250. Proteolytic activity is indicated by the translucent bands in the gels. Samples: ovaries dissected from females of 1, 2, 3 and 4 days after detachment from the bovine; extract of eggs 1, 3, 4, 5, 7, 8, 12 and 20 days after oviposition; and extract of larvae of 5, 10, 15 and 20 days after (egg) hatching.

\section{Enzyme purity}

The enzyme purity was checked by capillary electrophoresis as described (Kist, Termignoni \& Grieneisen, 1994). Briefly, the sample was labelled with fluorescamine and applied to a capillary $(75 \mu \mathrm{m}$

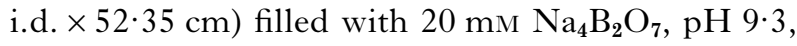
in methanol $(15 \%, \mathrm{v} / \mathrm{v})$, to which a potential of $13 \mathrm{kV}$ $(30 \mu \mathrm{A})$ was applied. The components were detected by a $\mathrm{N}_{2}$ laser-induced fluorescence detection system. Fluorescamine was used in a very large excess in order to assure all primary amino groups of the protein were labelled and also to serve as an internal standard.

\section{Molecular weight determination}

Samples were subjected to sodium dodecyl sulfatepolyacrylamide gel electrophoresis (SDS-PAGE) $(14 \%)$ under non-denaturing and denaturing conditions (Laemmli, 1970). The electrophoresis was performed using a Bio-Rad Mini-Protean Cell II unit. Resolving and stacking gels were $14 \%$ and $5 \%$ polyacrylamide, respectively.

\section{Sensitivity to inhibitors}

The purified enzyme was incubated with $100 \mu \mathrm{M}$ phenylmethylsulfonyl fluoride (PMSF), $10 \mathrm{~mm}$, ethylenediaminetetraacetic acid (EDTA), $50 \mu \mathrm{M} \mathrm{Na}$ p-tosyl-lysine chloromethyl ketone (TLCK), $1 \cdot 4 \mu \mathrm{M}$ pepstatin A, $100 \mu \mathrm{M}$ chymostatin or $10 \mu \mathrm{M}$ L-transepoxysuccinyl-L-leucylamido(4-guanidino)-butane (E-64) in $50 \mathrm{~mm}$ sodium citrate/sodium phosphate buffer, $\mathrm{pH} 3 \cdot 5$, for $15 \mathrm{~min}$ at room temperature. After addition of $10 \mathrm{~mm}$ DTT and a further $10 \mathrm{~min}$ incubation at $37^{\circ} \mathrm{C}$, the inhibitory activity of those compounds was determined by measuring the residual enzymatic activity upon $\mathrm{N}$-Cbz-Phe-Arg-MCA (as described above).
RESULTS

\section{Proteolytic activity in ovaries, eggs and larvae}

Zymograms in native polyacrylamide gels with copolymerized gelatin were used to verify the presence of proteolytic activity in $B$. microplus ovaries, eggs and larvae. Figure 1 shows that all extracts tested have proteolytic activity at acid $\mathrm{pH}$, indicated by the translucent bands in the gels. Enzyme(s) with proteolytic activity from ovaries and eggs migrated less than the larval proteolytic activity (Fig. 1), suggesting that the endopeptidases present in eggs and ovaries can be bigger than the ones present in larvae, or/and they can associate strongly with itself or with other proteins. The egg peptidase was selected for further studies.

\section{Purification of the egg peptidase activity}

An homogeneous enzyme preparation was achieved in 4 steps. Crude egg extracts were applied onto a MonoQ column and eluted with a $0-0.8 \mathrm{M} \mathrm{NaCl}$ gradient (Fig. 2A). Almost all vitellin, the major reserve protein of tick eggs, was eluted in the flowthrough, while the enzyme eluted at $0 \cdot 15-0.25 \mathrm{M}$ $\mathrm{NaCl}$. Judging by the brownish colour, an amount of vitellin was still contaminating the active fractions. Vitellin was eliminated from the peptidase activity by the autolysis step. Figure 3 shows an electrophoretic analysis of the material after the autolysis, in the presence and absence of E-64, a specific cysteine endopeptidase inhibitor. The gels show that, as autolysis proceeds, egg proteins with high molecular weight are hydrolysed yielding intermediates of lower molecular weight (Fig. 3). After a $60 \mathrm{~min}$ incubation, the high molecular weight bands were hardly visible, and after $180 \mathrm{~min}$ they virtually disappeared. At this time, the only remaining visible protein bands were of $\sim 55$ and $\sim 30 \mathrm{kDa}$. At any incubation time, hydrolysis was fully inhibited by E-64, indicating that the reaction is carried out by a cysteine endopeptidase. 
Table 1. Purification protocol and recovery

\begin{tabular}{|c|c|c|c|c|c|c|}
\hline \multirow{2}{*}{$\begin{array}{l}\text { Purification } \\
\text { step }\end{array}$} & \multirow{2}{*}{$\begin{array}{l}\text { Volume } \\
(\mathrm{ml})\end{array}$} & \multirow{2}{*}{$\begin{array}{l}\text { Protein } \\
(\mathrm{mg})\end{array}$} & \multicolumn{2}{|l|}{ Activity } & \multirow{2}{*}{$\begin{array}{l}\text { Yield } \\
(\%)\end{array}$} & \multirow{2}{*}{$\begin{array}{l}\text { Purification } \\
\text { fold }\end{array}$} \\
\hline & & & Total $(\mathrm{U})^{*}$ & Specific (U/mg) & & \\
\hline Extract & $5 \cdot 7$ & 272 & 68 & $0 \cdot 25$ & $-\dagger$ & - \\
\hline Mono Q & $6 \cdot 5$ & 60 & 1688 & 28 & 100 & 1 \\
\hline Autolysis & $5 \cdot 9$ & 14 & 1874 & 134 & 111 & 5 \\
\hline Superdex 75 & $2 \cdot 8$ & $3 \cdot 7$ & 1310 & 354 & 78 & 13 \\
\hline Mono Q & $1 \cdot 0$ & $0 \cdot 4$ & 740 & 1947 & 44 & 70 \\
\hline
\end{tabular}

* $\mathrm{U}=\mathrm{mFU} / \mathrm{min}$

$\dagger$ The activity present in the crude extract was not considered as $100 \%$ because enzyme activity is increased after the first purification step.

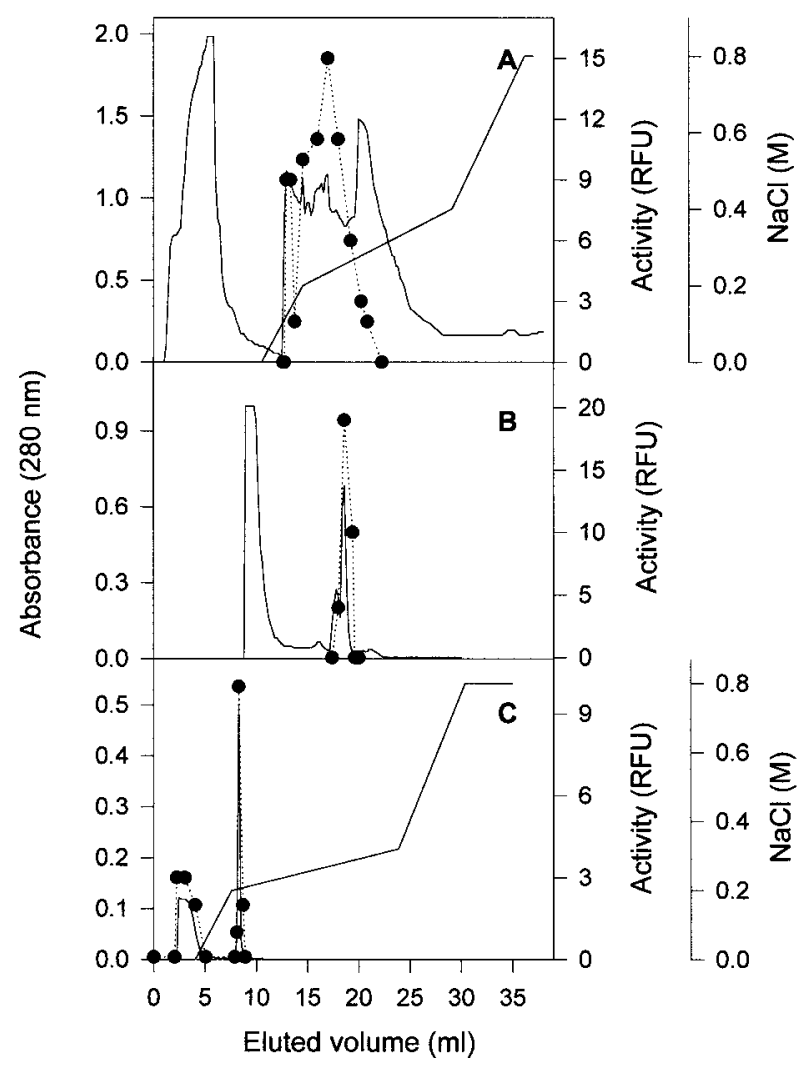

Fig. 2. Purification of the egg peptidase activity. (A) MonoQ1 - egg homogenate was applied onto a MonoQ column previously equilibrated with $10 \mathrm{~mm}$ sodium phosphate buffer, $\mathrm{pH} 7 \cdot 2$. Proteins were eluted with a $0-0.8 \mathrm{M} \mathrm{NaCl}$ gradient. (B) Superdex 75 - the supernatant from the autolysis step (see Materials and Methods section) was concentrated and applied onto a gel filtration chromatography column equilibrated with $10 \mathrm{~mm}$ acetate buffer, $\mathrm{pH} 4 \cdot 0$. (C) MonoQ2 - fractions from Superdex 75 showing activity were pooled and applied onto a MonoQ column previously equilibrated with $10 \mathrm{~mm}$ acetate buffer, $\mathrm{pH} 4 \cdot 0$; the sample was eluted with a $0-0.8 \mathrm{M} \mathrm{NaCl}$ gradient. Protein elution was monitored at $280 \mathrm{~nm}$. Fractions were assayed upon the substrate $N$-carboxybenzoyl-Phe-Arg-MCA. The solid line represents protein elution, the dotted line, enzyme activity and the stepped line, the salt gradient.
After the autolysis step, the supernatant fraction containing proteolytic activity was applied onto a gel filtration column (Fig. 2B). The activity eluted at 17$19 \mathrm{ml}$, coinciding with 1 of the major protein peaks. These fractions were pooled and submitted to a second anion-exchange (Mono Q) column, equilibrated with sodium acetate buffer, $\mathrm{pH} 4 \cdot 0$. Under these conditions, some of the activity eluted in the flowthrough and the retained activity eluted as a single sharp protein peak, at $0 \cdot 3 \mathrm{M} \mathrm{NaCl}$ (Fig. 2C). An outline of the purification is presented in Table 1 . The activity increased considerably after the first purification step (Mono Q), and this sample was thus taken as $100 \%$ activity to calculate yield and purification fold. The increase in activity after the first anion-exchange may be due to removal of vitellin excess that interferes with the enzyme activity.

The purity of the enzyme preparation is demonstrated in Fig. 4A, which shows a single protein band in native PAGE. To confirm this result, the preparation was also checked by free-zone capillary electrophoresis, a more sensitive method. Again, only 1 protein signal was observed (Fig. 4C). In SDSPAGE (Fig. 4B), however, 2 protein bands, one of approximately $17000 \mathrm{Da}$ and another of $22000 \mathrm{Da}$ (Fig. 4B, lane 3), were observed, suggesting that the peptidase may be a dimer. Surprisingly, these 2 bands became 1 broad band, ranging from $13000 \mathrm{Da}$ to $16000 \mathrm{Da}$, under reducing conditions (Fig. 4B, lane $2)$. This is an indication that the endopeptidase has peptide chains connected by disulfide bridges.

\section{Optimum pH and temperature}

Using a synthetic fluorogenic substrate, the cysteine endopeptidase showed maximal activity at $\mathrm{pH} 4 \cdot 0$ (Fig. 5A) and the optimum temperature was $50{ }^{\circ} \mathrm{C}$ (Fig. 5B).

\section{Effect of inhibitors}

The effect of a variety of compounds upon the activity of the purified proteinase is shown in Table 2. As the 
Table 2. Enzyme inhibition by proteinase inhibitors

(The purified Boophilus microplus egg enzyme was pre-incubated with the indicated inhibitors for $15 \mathrm{~min}$ at room temperature, and assayed for residual activity using $N$-Cbz-Phe-Arg-MCA as substrate.)

\begin{tabular}{lllr}
\hline \hline Inhibitor & Specificity & Concentration (mM) & Inhibition (\%) \\
\hline E-64 & Cysteine & $0 \cdot 01$ & 100 \\
Leupeptin & Cysteine & $0 \cdot 01$ & 100 \\
TLCK & Serine/cysteine & $0 \cdot 1$ & 100 \\
Chymostatin & Serine/cysteine & $0 \cdot 1$ & 100 \\
PMSF & Serine/cysteine & $0 \cdot 1$ & 33 \\
Pepstatin A & Aspartic & $0 \cdot 001$ & 0 \\
EDTA & Metallo & $0 \cdot 5$ & 0 \\
\hline \hline
\end{tabular}
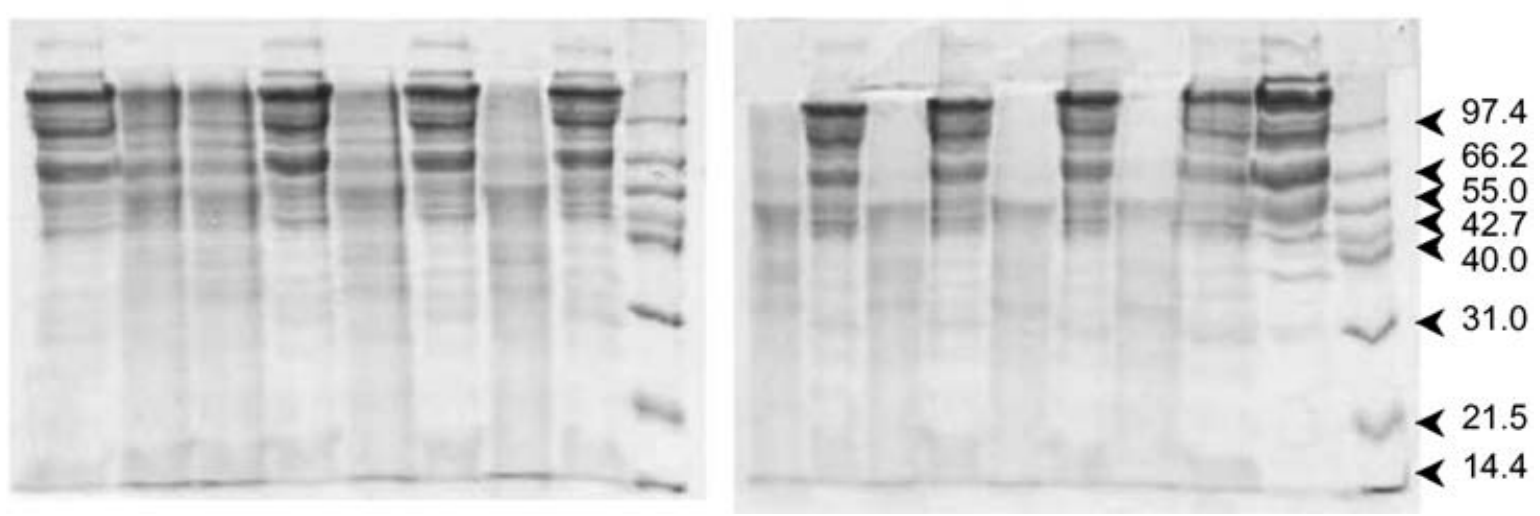

Fig. 3. Analysis by SDS-PAGE (12.5\%) of autolysis products. Active fractions from MonoQ1 were incubated at $37^{\circ} \mathrm{C}$, in the presence or absence of E-64 $(10 \mu \mathrm{M})$, after adjusting the $\mathrm{pH}$ to $3 \cdot 5$ with $1 \mathrm{M}$ citric acid. At the indicated times, aliquots $(67 \mu \mathrm{g})$ were taken and analysed by SDS-PAGE $(12 \cdot 5 \%)$. The presence of E-64 is indicated by ${ }^{\mathrm{i}} .180^{\mathrm{n}}$ shows an assay done in sodium phosphate buffer, $\mathrm{pH} 7 \cdot 2(\mathrm{n}=$ neutral). MW, molecular weight standards.

enzyme has no activity in the absence of DTT, this compound was used to activate the enzyme prior to determination of the residual activity. E-64, a specific cysteine endopeptidase inhibitor, leupeptin, TLCK and chymostatin completely inhibited the enzyme activity. The enzyme was partially inhibited by PMSF and was insensitive to pepstatin A and EDTA. The requirement for DTT and sensitivity to E-64 strongly suggest that the enzyme is a cysteine endopeptidase.

\section{Activity with synthetic peptides}

The enzyme activity was evaluated upon a panel of synthetic substrates (Table 3 ). As, in these substrates, the hydrolysable amide bond is the one between the peptide and the fluorophorous group, we could identify the aminoacid residues at $\mathrm{P}_{1}$ and $\mathrm{P}_{2}$ subsites that are preferred by the enzyme. Among them, the higher activity was upon $\varepsilon-\mathrm{NH}_{2}$-Cap-(SBzl)C-MCA and $N$-carboxibenzoyl-Phe-Arg-MCA. The enzyme also showed activity upon $\varepsilon-\mathrm{NH}_{2}$-Cap-Leu-PheMCA and $\varepsilon-\mathrm{NH}_{2}$-Cap-Leu-(OBzl)Thr-MCA. No activity upon the other peptidyl-methylcoumarin substrates was observed (Table 3). According to these results, the enzyme was more active upon substrates with a hydrophobic or a basic residue in $\mathrm{P}_{1}$, and a hydrophobic reside in $\mathrm{P}_{2}$. This specificity pattern, a basic residue in $\mathrm{P}_{1}$ and a hydrophobic residue in $\mathrm{P}_{2}$, was also observed in peptidyl-p-nitroanilide substrates (not shown).

\section{Activity upon proteins}

Zymograms showed that the partially purified enzyme was able to hydrolyse, in addition to vitellin, haemoglobin, gelatin and bovine serum albumin (BSA), whereas activity upon ovalbumin was barely observed (Fig. 6). Activities from crude extracts are also shown (Fig. 6, lane 3), although they were more difficult to visualize because most of the translucent bands were covered by the excessive amount of protein from the extract.

\section{DISCUSSION}

Our results demonstrate the presence of an endopeptidase activity in $B$. microplus unfed larvae, ingurgitated female ovaries and eggs. Differences in the electrophoretic migration of the endopeptidase activities may indicate the presence of distinct enzymes in each tick stage or organ. Since eggs are very 
A

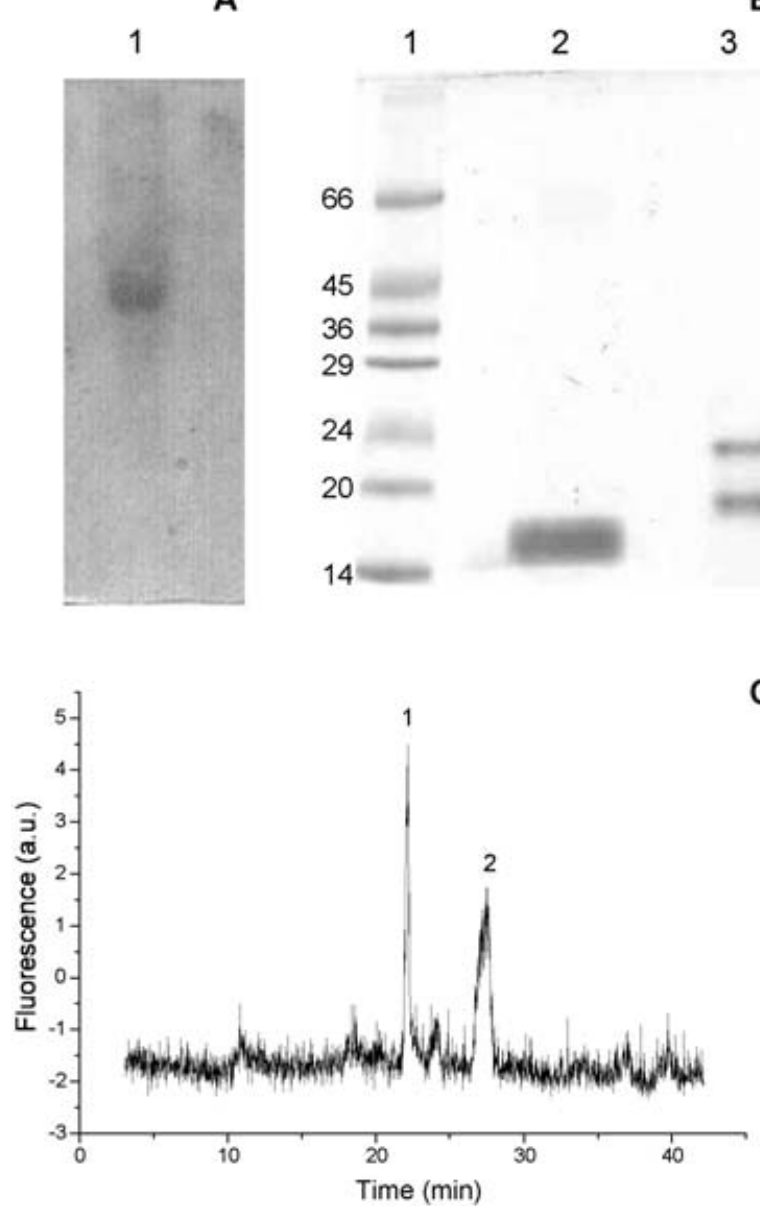

Fig. 4. (A) Electrophoresis of the purified cysteine endopeptidase $(40 \mu \mathrm{g})$ in $1.5 \%$ native-polyacrylamide gel (without SDS). (B) Electrophoresis of the purified cysteine endopeptidase $(50 \mu \mathrm{g})$ in SDS-PAGE (14\%). (1) Molecular weight standards (Low-Range Sigma); (2) enzyme reduced by $\beta$-mercaptoethanol; (3) enzyme without reduction. Protein was detected by colloidal Coomassie staining. (C) Capillary electrophoresis of the purified enzyme (for experimental conditions see Materials and Methods section). Peak 1 purified enzyme, peak 2 excess of fluorescamine.

rich in one single protein, vitellin, $13-7 \cdot 5 \mu \mathrm{g} \mathrm{VT} / \mathrm{egg}$, (Logullo et al. 2002) and its hydrolysis is of paramount importance for embryo nutrition, we decided to investigate the egg vitellin-degrading activity.

Tick oogenesis starts in the female ovary soon after blood feeding has begun. Vitellogenin produced in the fat body, and present in the maternal haemolymph, is matured to vitellin, which then accumulates in oocytes (Diehl, Aeschlimann \& Obenchain, 1982). Proteins, mainly vitellin, lipids and sugars constitute the yolk granules, which are fundamental to embryo development and larvae survival until they attach to the bovine and start blood feeding. Certain peptidases are transferred by endocytosis to the oocyte during vitellogenesis (Diehl, Aeschlimann \& Obenchain, 1982). In some species, they appear to be synthesized extraovarially as inactive
A
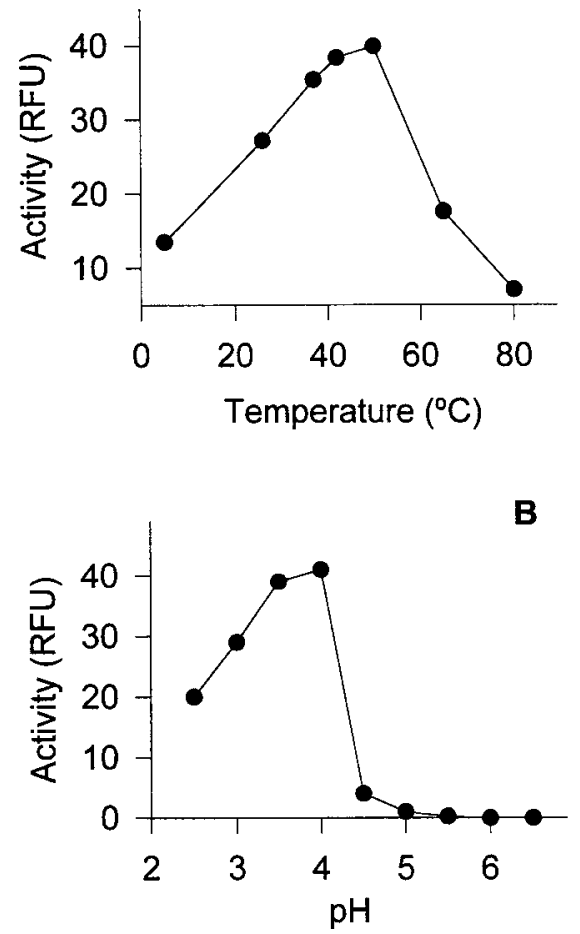

Fig. 5. Effect of temperature (A) and $\mathrm{pH}(\mathrm{B})$ on the activity of partially purified cysteine endopeptidase (after Superdex 75). The activity was tested upon MCAGln-Ser-Ser-Arg-His-Arg-Arg-Ala-Leu-Gln-EDDnp as described in the Materials and Methods section.

pro-endopeptidases (Ribolla \& De Bianchi, 1995; Nussenzveig, Oliveira \& Masuda, 1992), which are associated with vitellin (VT) in the yolk granules and activated by acidification (Fagotto, 1995). This seems to be the case of the B. microplus egg endopeptidase now described. This enzyme is tightly associated with VT, whose contamination is easily detected by the brownish colour conferred from its high hemebinding capacity. Actually, B. microplus vitellin binds more than 40 heme molecules per vitellin molecule (Logullo et al. 2002). Several chromatographic procedures, including hydrophobic interaction and addition of $1 \mathrm{~m}$ glucose to the gel filtration buffer, were attempted before we could successfully free VTDCE from VT. Incubation of the enzyme preparation with endoglycosidase $\mathrm{F}$ was equally inefficient. Vitellinfree VTDCE was obtained by VT degradation achieved by acidification and subsequent incubation of the active material eluted from the first Mono Q column. The acidification required for VT degradation, which does not occur at neutral $\mathrm{pH}$, coincides with VTDCE optimum $\mathrm{pH}$. Clearly, $\mathrm{pH}$ alone is not sufficient to degrade VT, as inhibition of the enzyme activity with the cysteine inhibitor E-64 did not result in substrate degradation despite the acid $\mathrm{pH}$. A similar example is a cathepsin B-like cysteine proteinase from Drosophila that is associated to yolk granules and blockage of acidification prevents yolk degradation (Medina et al. 1988). Degradation of VT 
Table 3. Activity of the purified enzyme upon fluorogenic peptide substrates

(Purified VTDCE $(7 \cdot 6 \mu \mathrm{g})$ was incubated with $50 \mathrm{~mm}$ sodium citrate/sodium phosphate buffer, pH $3 \cdot 5,10 \mathrm{~mm}$ DTT at $37^{\circ} \mathrm{C}$. After $10 \mathrm{~min}$, the fluorogenic substrates were added $(100 \mu \mathrm{M}$, final concentration) to a total volume of $100 \mu \mathrm{l}$. Hydrolysis was monitored at $370 \mathrm{~nm} / 460 \mathrm{~nm}$, in a fmax Microplate Reader.)

\begin{tabular}{llc}
\hline \hline Fluorogenic substrates & $\begin{array}{l}\text { Activity } \\
\text { (pmoles MCA/min) }\end{array}$ & Activity (\%) \\
\hline$\varepsilon$-NH 2 -Cap-(SBzl)-C-MCA & $14 \cdot 2$ & 100 \\
$N$-Cbz-Phe-Arg-MCA & $10 \cdot 20$ & 72 \\
$\varepsilon-\mathrm{NH}_{2}$-Cap-Leu-Phe-MCA & $1 \cdot 29$ & 9 \\
$\varepsilon-\mathrm{NH}_{2}$-Cap-Leu-(Obzl)-Thr-MCA & $0 \cdot 88$ & 6 \\
$N$-t-Boc-Glu-Ala-Arg-MCA & 0 & 0 \\
$N$-t-Boc-Gln-Ala-Arg-MCA & 0 & 0 \\
$N$-t-Boc-Gly-Arg-MCA & 0 & 0 \\
$N$-t-Boc-Ile-Glu-Gly-Arg-MCA & 0 & 0 \\
$N$ - $\alpha$-benzoyl-Lys-Arg-MCA & 0 & 0 \\
$N$-t-Boc-Gln-Val-Pro-Arg-MCA & 0 & 0 \\
\hline \hline
\end{tabular}
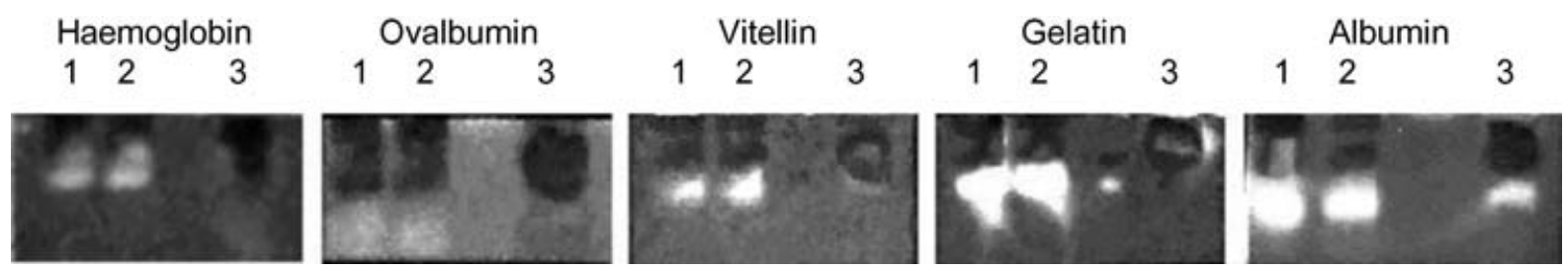

Fig. 6. Specificity of the partially purified enzyme upon natural substrates. A partially purified enzyme was electrophoresed in polyacrylamide gels $(7 \cdot 5 \%)$ co-polymerized with $0 \cdot 1 \%$ haemoglobin, $0 \cdot 1 \%$ ovalbumin, $0 \cdot 1 \%$ vitellin, $0 \cdot 1 \%$ gelatin or $0 \cdot 1 \%$ albumin. After the electrophoretic separation, gels were incubated overnight in $0 \cdot 1 \mathrm{M}$ sodium acetate buffer, $\mathrm{pH} 3 \cdot 5$, containing $5 \mathrm{~mm}$ DTT, at $37^{\circ} \mathrm{C}$. After incubation, gels were washed with water and stained with Coomassie Brilliant Blue R-250. A see-through band indicates degradation of substrate by the enzyme. Lanes 1 and 2: partially purified enzyme after MonoQ1 and Superdex 75, respectively; lane 3: whole egg extract.

by V'TDCE was confirmed when purified V'T was incubated with purified VTDCE (results not shown).

This strong association between VTDCE and VT may maintain the enzyme saturated with VT and in this way increasing its hydrolysis. This could be of physiological relevance for V'T utilization by the embryo. The VT would block the access of synthetic substrates to the active site, thus explaining the increase in the enzyme activity upon the $N$-Cbz-PheArg-MCA after the first purification step.

Analysis by native PAGE and capillary electrophoresis show that VTDCE was obtained in a homogeneous form. On the other hand, SDS-PAGE (under non-reducing conditions) revealed 2 protein bands (22 $\mathrm{kDa}$ and $17 \mathrm{kDa})$, indicating that the enzyme is formed by 2 non-covalently bound subunits. Another possibility is that a fragment of VT remained bound to the enzyme and was dissociated by SDS during electrophoresis. This is unlikely, though, since the preparation was not recognized by a polyclonal antiVT antibody (Da Silva Vaz Jr, Ozaki \& Masuda, 1994); contamination, if present, would be less than $10^{-4} \mu \mathrm{g} \mathrm{Vt} / \mu \mathrm{g}$ VTDCE. In addition, this preparation did not absorb at $400 \mathrm{~nm}$ (VT maximum absorbance wavelength). Under reducing conditions, only 1 diffuse protein band was observed, corresponding to a molecular range from $13 \mathrm{kDa}$ to $16 \mathrm{kDa}$. This result suggests that each subunit observed in SDS-PAGE would have at least 2 peptide chains linked by S-S bridges. Heteropolymeric endopeptidases have been described in eggs of other arthropods. Eggs of the argaside tick. O. moubata has a cathespin L-like acid proteinase that presents one peptide chain in native-gelatin-copolymerised-gels and two chains (37 and $39 \mathrm{kDa}$ ) in gelatin-copolymerised SDS-PAGE (Fagotto, 1990). Likewise, B. germanica contains a cysteine protease with three polypeptides of approximately $29 \mathrm{kDa}$ each (Liu et al. 1996).

The strict requirement of the purified enzyme for DTT and its inhibition by E-64 and leupeptin indicate VTDCE is a cysteine endopeptidase. Proteases of the cysteine endopeptidase subclass often participate in arthropod yolk degradation, as has been reported for B. germanica, Drosophila melanogaster, O. moubata and Bombyx mori (Liu et al. 1996; Medina et al. 1988; Fagotto, 1990; Kageyama \& Takahashi, 1990).

VTDCE was able to hydrolyse the synthetic substrates $\varepsilon-\mathrm{NH}_{2}-\mathrm{Cap}-(\mathrm{SBzl})-\mathrm{Cys}-\mathrm{MCA}$ (that has a hydrophobic aminoacid in $\mathrm{P}_{1}$ ) and $N$-Cbz-Phe-ArgMCA, which is a substrate highly susceptible to hydrolysis by cathepsin $\mathrm{L}$ but is also hydrolysed 
by cathepsin B (Medina et al. 1988). Based on this specificity and the optimum $\mathrm{pH}(\mathrm{pH} 4 \cdot 0)$, we can suggest that VTDCE is a cathepsin L-like enzyme. We exclude the possibility that VTDCE is $B m \mathrm{c} 11$, a cathepsin L-like enzyme previously described in B. microplus larvae, because they differ in substrate specificity, sensitivity to inhibitors and optimum $\mathrm{pH}$ (Renard et al. 2000). Further support to this idea is that the synthetic substrates $N$-t-Boc-Glu-Ala-ArgMCA, $N$-t-Boc-Gln-Ala-Arg-MCA, N-t-Boc-GlnVal-Pro-Arg-MCA are hydrolysed by $B m \mathrm{c} 11$ but not by VTDCE. The VTDCE, like most members of the papain family, hydrolyses substrates with hydrophobic aminoacids in $\mathrm{P}_{1}$ and/or $\mathrm{P}_{2}$, or with arginine or lysine residues in $\mathrm{P}_{1}$.

VTDCE hydrolyses haemoglobin, albumin, gelatin and vitellin. This shows that VTDCE has a broad specificity, in agreement with its ability to fully degrade V'T. Nevertheless, we believe that the physiological substrate for VTDCE is vitellin, since VT is the major protein of the yolk granule and is naturally associated with the enzyme.

Altogether, our results demonstrate that VTDCE is a major enzyme involved in yolk processing during B. microplus embryogenesis. Another important $B$. microplus enzyme implicated in this process is the aspartic proteinase BYC (Boophilus Yolk procathepsin) (Logullo et al. 1998). Ticks fed on BYCvaccinated bovines presented functional bovine immunoglobulins circulating in haemolymph (Da Silva Vaz Jr et al. 1996). Moreover, cattle vaccinated with BYC presented a partially protective immune response against $B$. microplus infestation, mainly due to a decreased number of fertile eggs (Da Silva $\mathrm{Vaz} \mathrm{Jr}$ et al. 1998). Considering that VT degradation results from the activity of both enzymes (BYC and VTDCE), VT degradation would be even more impaired if, in addition to antibodies against BYC, bovine antibodies against VTDCE could also be raised.

The authors are grateful to Dr Jair R. Chagas and Dr Luiz Juliano (Escola Paulista de Medicina, Universidade Federal de São Paulo, Brasil) for the synthetic fluorogenic substrate MCA-Gln-Ser-Ser-Arg-His-Arg-Arg-Ala-LeuGln-EDDnp. We also thank Dr Tarso B. Kist and Sandro Hillebrand for the capillary electrophoresis of VTDCE. This work was supported by grants from Financiadora de Estudos e Projetos (PRONEX-FINEP), Programa de Apoio ao Desenvolvimento Científico e Tecnológico (PADCT), Fundação de Amparo à Pesquisa do Estado do Rio Grande do Sul (FAPERGS) and Conselho Nacional de Desenvolvimento Científico e Tecnológico (CNPq-PIBIC). A. S. and P. C. S. were recipients of PIBIC-CNPq scholarships.

\section{REFERENCES}

CANAL, C. W., MAIA, H. M., DA SILVA VAZ Jr, I., CHIES, J. M., FARIAS, N. A., MASUDA, A., GONZALES, A. J. C., OZAKI, L. S. \& DEWES, H. (1995). Changing of vitellin-related peptides during development of the cattle tick Boophilus microplus. Experimental and Applied Acarology 19, 325-336.
CHO, W. L., TSAO, S. M., HAYS, A. R., WALter, R., CHEN, J. S., SNIGIREvskaya, E. S. \& RAIKHEL, A. S. (1999). Mosquito cathepsin B-like protease involved in embryonic degradation of vitellin is produced as a latent extraovarian precursor. Fournal of Biological Chemistry 274, 13311-13321.

DA Silva VAZ Jr, I., MARTineZ, R. H., Oliveira, A., HECK, A., LOGUllo, C., GONZALES, J. C., DeWEs, H. \& MASUdA, A. (1996). Functional bovine immunoglobulins in Boophilus microplus hemolymph. Veterinary Parasitology 62, 155-160.

DA Silva VAZ Jr, I., OZAKI, L. S. \& MASUdA, A. (1994). Serum of Boophilus microplus infested cattle reacts with different tick tissues. Veterinary Parasitology 52, 71-78.

DA Silva VAZ Jr, I., LOGUllo, C., SORGine, M., Velloso, F. F., ROSA DE LIMA, M. F., GONZALES, J. C., MASUdA, H., OLIVEIRA, P. L. \& MASUDA, A. (1998). Immunization of bovines with an aspartic proteinase precursor isolated from Boophilus microplus eggs. Veterinary Immunology and Immunopathology 66, 331-341.

Diehl, P. A., AESChlimAnN, A. \& OBENCHAin, F. D. (1982). Tick reproduction: oogenesis and oviposition. In Physiology of Ticks (ed. Obenchain, F. D. \& Galun, R.), pp. 277-350. Pergamon Press, Oxford.

FAGotTo, F. (1990). Yolk degradation in tick eggs: I. Occurrence of a cathepsin L-like acid proteinase in yolk spheres. Archives of Insect Biochemistry and Physiology 14, 217-235.

FAGOTTO, F. (1991). Yolk degradation in tick eggs: III. Developmentally regulated acidification of the yolk spheres. Development Growth and Differentiation 33, 57-66.

FAGOTTO, F. (1995). Regulation of yolk degradation, or how to make sleepy lysosomes. Fournal of Cell Science $\mathbf{1 0 8}$, 3645-3647.

FAGotTo, F. \& MAXFIEld, F. R. (1994). Yolk platelets in Xenopus oocytes maintain an acidic internal $\mathrm{pH}$ which may be essential for sodium accumulation. Fournal of Cell Biology 125, 1047-1056.

HEUSSEN, C. \& DOWDLE, E. B. (1980). Electrophoretic analysis of plasminogen activators in polyacrilamide gels containing sodium dodecyl sulfate and copolymerized substrates. Analytical Biochemistry 102, 196-202.

Kageyama, T. \& TAkahashi, s. Y. (1990). Purification and characterization of a cysteine proteinase from silkworm eggs. European Fournal of Biochemistry 193, 203-210.

KIST, T. B. L., TERMignONI, C. \& GRIENEISEN, H. P. (1994). Capillary zone electrophoresis separation of kinins using a novel laser fluorescence detector. Brazilian Fournal of Medical and Biological Research 27, 11-19.

LAEMMLI, U. K. (1970). Cleavage of structural proteins during the assembly of the head of bacteriophage $\mathrm{T}_{4}$. Nature, London 227, 680-685.

LiU, X., McCarron, R. C. \& NORdin, J. H. (1996). A cysteine protease that processes insect vitellin. Purification and partial characterization of the enzyme and the proenzyme. Fournal of Biological Chemistry 271, 33344-33351.

LOGUllo, C., DA Silva VAZ Jr, I., SORGINe, M. H., PAIVA-Silva, G. O., FARIA, F. S., ZINGALI, R. B., DE LIMA, M. F., ABREU, L., Oliveira, E. F., Alves, E. W., MASUdA, H., GONZALEs, J. C., MASUDA, A. \& OLIVEIRA, P. L. (1998). Isolation of an aspartic proteinase precursor from the egg of a hard tick, Boophilus microplus. Parasitology 116, 525-532. 
LOGUllo, C., MORAEs, J., DANSA-PETRETSKi, M., DA Silva VAZ Jr, I., MASUdA, A., SORGINE, M. H. F., BRAZ, G. R. \& OLIVEIRA, P. L. (2002). Binding and storage of heme by vitellin from the cattle tick. Insect Biochemistry and Molecular Biology 32, 1805-1811.

MALLYA, S. K., PARTIN, J. S., VALDIZAN, M. C. \& LENNARZ, W. J. (1992). Proteolysis of the major yolk glycoproteins is regulated by acidification of the yolk platelets in sea urchin embryos. Fournal of Cell Biology 117, 1211-1221.

medina, M., LeOn, P. \& VAllejo, c. G. (1988). Drosophila cathespin B-like proteinase: a suggested role in yolk degradation. Archives of Biochemistry and Biophysics 263, 355-363.

NUSSENZVEIG, R. H., OLIVEIRA, P. L. \& MASUdA, H. (1992). Identification of yolk platelet-associated hydrolases in the oocytes of Rhodnius prolixus. Archives of Insect Biochemistry and Physiology 21, 253-262.
Oliveira, M. C., HiRATA, I. Y., ChaGAS, J. R., BOSCHCOV, P., GOMES, R. A., FIGUEIREdo, A. F. \& JULIANO, L. (1992). Intramolecularly quenched fluorogenic peptide substrates for human renin. Analytical Biochemistry 203, 39-46.

RENARD, G., GARCIA, J. F., CARdoso, F. C., RICHTER, M. F., SAKANARI, J. A., OZAKI, L. S., TERMIGNONI, C. \& MASUDA, A. (2000). Cloning and functional expression of a Boophilus microplus cathepsin L-like enzyme. Insect Biochemistry and Molecular Biology 30, 1017-1026.

RIBOLla, P. E. \& DE BIANCHI, A. G. (1995). Processing of procathepsin from Musca domestica eggs. Insect Biochemistry and Molecular Biology 25, 1011-1017.

WARBURG, O. \& CHRISTIAN, W. (1941). Isolierung und Kristallisation des Garungsferments enolase. Biochemische Zeitschrift 310, 384-421. 